\title{
Frontier, Migrations, Social Rights and Social Work
}

According to the World Migration Report 2018 (WMR 2018) of the International Organization for Migration, migratory movements are complex phenomena involving several different situations, including both international movements of population, and the movements occurring within different nation-states (MCAULIFFE; RUHS, 2017).

In times of capital-imperialism (using the category proposed by Virginia Fontes), hundreds of millions of people have been forced to leave their places of origin because, as Pietro Basso (2004) asserts, migration never has a voluntary nature; it is always forced, due to structural economic, social, political, cultural or environmental causes. The numbers released by the WMR 2018 are overwhelming, and we know that statistics do not tell the whole story. By 2015 there were 243.7 million emigrants, which amounted to $3.3 \%$ of the total population of the planet and represented an increase of 71 million people (41.1\%) compared to the beginning of the millennium and about 159 million (188.5\%) compared to 1970. It should be noted that the number of emigrants in 2015 already exceeded the 230 million people that projections made in 2003 expected for 2050 (MCAULIFFE; RUHS, 2017).

However, this number is not the largest contingent of population in movement. The largest part of it is internal, reaching 740 million in 2009, according to the United Nations Development Program data cited by WMR 2018 (MCAULIFFE; RUHS, 2017). This refers to the 40.3 million people internally displaced, identified in 2016 by the Internal Displacement Monitoring Center and the 22.5 million refugees estimated by the United Nations High Commissioner for Refugees. These two categories experienced a significant increase in the last decades due to conflicts happening worldwide (MCAULIFFE; RUHS, 2017).

The WMR 2018 says, in addition, that the majority of those moving to destinations outside their country of origin are men (52\%) and the overwhelming majority are of working age (72\% are aged between 20 and 64). Data on the countries of origin and destination show that half of the growing number of workers forced to emigrate comes mainly from Asia, with particular relevance to the Indian subcontinent (India - around 15 million people--, Pakistan, Bangladesh), but also China. It is important to mention Mexico, which is the second largest exporter of workforce, after India. Migratory flows are mainly directed towards the central countries of capitalism, with the United States and Germany leading the way, as well as regions such as the Arabian Peninsula or certain parts of Asia (MCAULIFFE; RUHS, 2017).

Notwithstanding the important migratory flows observed in the late nineteenth to early twentieth century, this theme is far from being a primary object of study in the period of foundation and consolidation of the social sciences, and in particular of sociology. In fact, the classical authors paid little attention to it, even though they laid the groundwork for future interpretations of the phenomenon of migration.

Emile Durkheim addressed the issue in his book Division of Labour in Society (1984), analyzing the growth of cities. His main contributions lie in the formulation of the categories, social cohesion, social integration or socialization, as well as the emphasis given to education.

Max Weber alluded to the theme in some of his best known works, such as The Protestant Ethics and the Spirit of Capitalism (1983) and Economy and Society (1999). His main work on this theme was

(C) The Author(s). 2018 Open Access This article is distributed under the terms of the Creative Commons Attribution-NonCommercial 4.0 International License (http://creativecommons.org/licenses/by-nc/4.0/), which permits use, distribution, and reproduction in any medium, since it's for non-commercial purposes, and provided you give appropriate credit to the original author(s) and the source, provide a link to the Creative Commons license, and indicate if changes were made. 
Developmental Tendencies in the Situation of East Elbian Rural Labourers (1984), where he observed that German workers left certain areas and were replaced by Poles, possibly jeopardizing national sovereignty. However, his later work on migration used his theoretical perspective, which for history, became known as methodological individualism and proved to be far more important than these considerations.

Georg Simmel (1972) also worked on this topic in some of his articles. His thinking about the role of the individual, the problem of assimilation, or the thesis of differentiation influenced future works, first of all those of the Chicago School.

In the work of Karl Marx, migration is presented in a more developed way than by the other authors. He interprets migrations as a dimension of the process of capitalist accumulation. The issue of migration can be found in the works Capital (1990-2017) and On Britain (1962), written in collaboration with Engels. A large part of the book is dedicated to Irish emigration, which is also treated, in various dimensions, in Engels' The Condition of the Working Class in England (2008).

In the classical Marxist field, reference is made to Rosa Luxemburg, who in The Accumulation of Capital (1970) discusses this topic in the context of the historical conditions of accumulation, and to Lenin, author of a little-known article entitled Capitalism and Workers' Immigration (1985), where he reflects on migration processes and their consequences. Beginning with the assertion that capitalism has developed a particular form of migration by attracting workers from the "backward countries" to the more developed ones by offering better wages. Lenin concludes that this causes a widening of the gap between countries, since the population that migrate is the "most energetic and most apt for work". He ends by noting the policy of the bourgeoisie, aiming at the division among the workers, in launching the autochthonous against the emigrants, as we are witnessing today.

If the founders of sociology did not grant a central status to migratory flows in their scientific production, neither did the geographer Ernest Ravenstein $(1885,1889)$, who in the 1880 's, wrote two works that proved to be fundamental to some of the future studies on this subject.

It was only in the mid/late 1910s that a field of study on the migratory phenomena in sociology will begin, with the pioneering work of William I. Thomas and Florian Znaniecki (1984) on Polish immigrants in the USA and Robert E. Park (1984) in the field of integration and urban conflicts. From these enterprises of the Chicago School, the field of studies has developed and currently the theoretical offer is abundant and quite diversified.

The theoretical proposal can be classified into two broad categories. Firstly, the micro-sociological analyzes, rooted in the neoclassical economic conceptions, but also in the methodological individualism of Weber and Simmel, who focus on the individuals and decision-making processes (considered rational) that they develop with the aim of migrating. Secondly, macro-sociological analyzes, which emphasize the importance of the structural constraints that compel the individual to migrate, refer to the perspective of Durkheim (in the case of the structural-functionalist current) or Marx.

The first category includes, in particular, attraction-repulsion and human capital theories which, despite their differences (for example, the emphasis on investment in training) are based on the common assumption that individuals, wishing to improve their living conditions and having a thorough knowledge of the obstacles in their regions of origin and the opportunities available elsewhere, decide (in a rational way) to migrate. It also includes the more marked sociological theories of the life cycle and social trajectories that emphasize either the existence of a relationship between individuals' life cycles and the propensity to migrate, or the existence of a relationship between the desire for professional and/or social mobility and the decision to migrate.

The second category includes, for example, the concepts based on the theory of labor market segmentation, which affirm that the leitmotiv for migration, especially internationally, is not found in individuals and their conditions of life, but on the fact that there was an explosion of employment in the secondary labor market in the countries central of capitalism.

It also includes institutional interpretations, which take different forms, depending on the type of institutions analyzed or the roles they perform in migratory processes. Depending also on the conceptions that focus on the study of social networks, of various kinds, in which individuals are included and can catalyze the migration movement or support it during its development, or those who give relevance to the bonds of solidarity that unite emigrants with the same geographical and/or ethnic origin in the places of destination.

Integrating this category are the theses that are linked to the neo-Marxist theory of the Wallerstein's (1979) world system, which considers that the development of capitalism created a global labor market characterized by the existence of surplus labor in peripheral countries and by strong asymmetries in terms of salaries between center and periphery, thus explaining the migratory flows.

Finally, they include the conceptions which, referring directly to Marx, situate migratory processes as the result of the existence of relative overpopulation in dependent countries, which is subject to an intense overexploitation that hinders its social reproduction. This overpopulation then moves to the central countries of 
capitalism where, although workers continue to be heavily exploited and denied access to social rights, they receive wages which, however low, are higher than those in their countries of origin. This labor force becomes indispensable for the process of capitalist accumulation, which is accentuated in times of crisis of capitalism. A consequence of this situation is the racist and xenophobic manifestations that have been occurring in many countries, as well as the imposition by states of more restrictive policies - nonetheless favoring capital - that have been analyzed by authors such as Pietro Basso (2016).

In an era of intensification of migratory movements, Revista Katalysis felt compelled to dedicate an issue to this theme. This issue will present a collection of articles that, based on a diversity of subjects and on methodological plurality, are also based on a homogeneous theoretical perspective rooted in historical materialism.

The first two articles, by Célia Vendramini and Maria Helena Abreu, contains a general theoretical framework. The first aims to "go beyond appearances", reflecting on migration in the light of the categories of historical materialism, showing what actually drives workers and their families to leave their places of origin for others either inside their own countries, or moving internationally. The second article discusses territory, analyzing it as a "socio-historical construct of globalized capital in crisis" and as the "ground of the class struggle".

The subsequent articles focus on international migration and its implications, in particular on the social policies and professional practices of those implementing them on the ground. This is the object of Evelyn Faquin, Líria Lanza and Paula Ribeiro's article, which looks at the state of Paraná as an empirical field. Juliana Muller, Karine Silva and Henrique Martins da Silveira discuss the new African immigration to Florianopolis, concluding that there is "a continuous process of making black populations invisible" and "the lack of specific policies from the state" toward emigrants.

Cross-border issues are discussed in the article by Helenara Fagundes, Vera Nogueira, Ineiva Kreutz and Daniela Castamann, which explores "the relationship between cross-border pacts and protocols in the area of health and the performance of political actors" at the border between Brazil and Uruguay. Eric Cardin's article presents the invaluable theoretical contributions of István Mészáros, reflecting on the social relations of work in border regions, including the state's performance on this issue; and Lislei Preuss, who studied the management of the Brazilian Unified Health System (SUS) in border regions.

The articles by Jaqueline Bertoldo, Karina Alcubierre and Soraya Conde respectively introduce the variables gender and age in their analyses. In the first, attention is given to migrant women who enter the labor market in unqualified, traditionally feminized occupations, such as domestic service. The second article presents the results of an innovative study that aimed to understand children's feelings and perceptions regarding their migration. Field work was carried out with children between the ages of four and six and their families.

Ednan Santos's article about the inhabitants of "migrant Cracolândia" is also innovative. After noting that $45 \%$ of people with drug or alcohol dependence in the region called Cracolandia ('crack land') do not come from São Paulo, the author questions whether dependence is the cause of migration or the consequence of a disappointment with the results of the migration process.

Finally, Walter Medina, Aura Serna and Edvânia Gomes' contribution, the only one that does not focus on the Brazilian reality, explores the changes and continuities in the use of the labor force in the gold mines of Colombia from the perspective of the Marxist political economy, evidencing the growing disqualification and exploitation.

The edition concludes with a section that includes five articles that deal with diverse themes, focusing on Brazil and/or other Latin American countries.

The first, by Maria Ozarina Silva and Valéria Lima, evaluates the impact of conditional cash transfer programs on the levels of poverty and social inequality in three countries - Brazil, Argentina and Uruguay. In the second, by Glauber Xavier, the concept of imperialism is problematized starting from the Marxist theory of dependence, evidencing its importance for the understanding of Latin American dependent capitalism. In the third, by Alicia Ali, home visits by Chilean social workers who work in public schools as a "strategy of professional activity" is discussed.

The final two articles focus on Brazil. The first by Vanda Burginski, is a critique of the neo-Keynesian and Neo-developmentalist concepts defended by ECLAC that, instead of being constituted as an alternative to the neoliberal project, are two ideological expressions of neoliberalism. The second, by Gisele Anselmo, Maria Mustafa and Salyanna Silva, analyzes the events surrounding Dilma Rousseff's impeachment and its consequences, seen as an "expression of denial of democracy" and as aiming to destroy the social rights gained over the last decades by men and women who, in the instigating theoretical reflection of Ricardo Antunes, make up the working class.

Paulo Marques Alves, Lisbon, 23 May 2018. 


\section{References}

ANTUNES, R. Os sentidos do trabalho: ensaio sobre a afirmação e a negação do trabalho. São Paulo: Boitempo Editorial, 2005.

BASSO, P.; Perocco, F. Immigrazione e trasformazione della società. 2. ed. Milano: Franco Angeli, 2004.

BASSO, P. Le racisme européen: critique de la rationnalité institutionnelle de l'oppression. Paris: Syllepse, 2016.

DURKHEIM, E. A divisão do trabalho social. 2. ed. Lisboa: Presença, 1984.

ENGELS, F. A Situação da classe trabalhadora na Inglaterra, São Paulo: Boitempo Editorial, 2008.

FONTES, V. M. O Brasil e o capital-imperialismo: teoria e história. 2. ed. Rio de Janeiro: UFRJ; Rio de Janeiro: EPSJV, 2010.

LÉNINE, V. I. O Capitalismo e a Imigração dos Operários. In: OBRAS Escolhidas de Lénine III. Lisboa: Avante, 1985. p. 119-122. (Coleção Obras Escolhidas de Lénine, t. 3).

LUXEMBURGO, R. A Acumulação do Capital: estudos sôbre a interpretação econômica do imperialismo. Rio de Janeiro: Zahar, 1970. MARX, K. O capital: crítica da economia política. Lisboa: Avante, 1990-2017. 8 v.

MARX, K.; ENGELS, F. On Britain. Moscovo: Foreign Languages Publishing House, 1962.

MCAULIFFE, M.; RUHS, M. (Ed.) World Migration Report 2018. Geneva: International Organization for Migration, 2017.

PARK, R. E.; BURGESS, E. W. The City: suggestions for investigation of human behavior in the urban environment. Chicago: University of Chicago, 1984.

RAVENSTEIN, E. The Laws of Migration, Journal of the Statistical Society of London, London, v. 48, n. 2, p. 167-235, June 1885. Disponível em: <https://www.jstor.org/stable/2979181>. Acesso em: 23 maio 2018.

RAVENSTEIN, E. The Laws of Migration, Journal of the Royal Statistical Society, London, v. 52, n. 2, p. 241-305, June 1889. Disponível em: <https://www.jstor.org/stable/2979333> Acesso em: 23 maio 2018.

SIMMEL, G. Sociología: estudios sobre las formas de socialización. Madrid: Alianza Editorial, 1972. 2 v.

THOMAS, W. I.; ZNANIECKI, F. The Polish Peasant in Europe and America. Urbana: University of Illinois, 1984.

WALLERSTEIN, I. The Capitalist World-Economy. Cambrige: Cambridge University, 1979.

WEBER, M. A Ética Protestante e o Espírito do Capitalismo. Lisboa: Presença, 1983.

WEBER, M. Economia e Sociedade: fundamentos da sociologia compreensiva. Brasília: UnB; São Paulo: Imprensa Oficial do Estado de São Paulo, 1999. 2 v.

WEBER, M. Die Lage der Landarbeiter im ostelbischen Deutschland. Tübingen: J.C.B. Mohr (Paul Siebeck), 1984.

\section{Paulo Marques Alves}

p.alves61@gmail.com

Doctor in Sociology from the ISCTE - University Institute of Lisbon (ISCTE-IUL)

Assistant Professor at the Sociology Department of the ISCTE - University Institute of Lisbon (ISCTE-IUL)

\section{ISCTE-IUL}

Sociology Department

Av. das Forças Armadas

Lisboa - Portugal

Postal Code: 1069-026 